\title{
Analysis on Invalid Marriage system
}

\author{
Hang Liu \\ Nanchang Institute of Science \&Technology, Nanchang Jiangxi 330108, China
}

Keywords: Invalid marriage; legal cause; declaring authority; legal consequence;

\begin{abstract}
The invalid marriage system is a newly established system by the marriage law in 2001, which fills the blank of legislation and is a great progress in the legislation of marriage. Invalid marriage is a violation of the marriage of the establishment of the elements of the illegal marriage, this article on the legal issues of invalid marriage, the authorities and the legal consequences of the defects are analyzed, and put forward a sound legislative proposals.
\end{abstract}

\section{Introduction}

The revised marriage law promulgated in April 28, 2001, this is the first time in the history of our country marriage law to establish of a separate chapter, which is in the legislative history of our country's first introduced the invalid marriage system, it is further improve China's legal system of marriage, it is one of the major achievements of China's marriage law amendment. In practice, the invalid marriage system to further improve the marriage system of our country, on the one hand, it can be said to be the key to China's marriage system, it is a part of the invalid marriage institution of the law of marriage, marriage system can better protect our country, on the other hand, it also can better prevent and punishment of illegal marriage, to indicate the direction of the marriage parties, it is conducive to the elimination of conflicts of law, improve applicable to the seriousness and authority of the marriage law. The invalid marriage system implemented in recent years, its role and effectiveness research, in practice not only protect the marriage system of our country, but also reduce the marriage disputes, enhance the guiding role of law. Of course, every thing has two sides, there are many defects and deficiencies in the practice of invalid marriage system in china. which is far from its own function. Therefore, it is necessary to make further research, in order to perfect the invalid marriage system in the future civil code.

\section{The concept of invalid marriage and its historical evolution}

Invalid marriage is a violation of the conditions of marriage, due to the lack of effective elements of marriage, and therefore does not have the legal effect of marriage. Since the emergence of marriage law in human society, legitimacy has become the essential attribute of marriage. Therefore, any era, any country should be through legal means for the establishment of the marriage provisions of various elements, including substantive elements and form elements. Only with the combination of these elements, only then recognized by the social system, the legal effect of marriage, the couple will have the rights and obligations.

Invalid marriage system has something to do with ancient law. Such as the law of ancient Babylon: the combination of marriage without prior agreement is invalid marriage. The ancient city of Rome civil law "the establishment of marriage must have the right to marry, the parties shall, should reach the legal age of marriage, the father or guardian shall obtain consent", which violates the conditions of marriage is assumed as informal marriage prohibitions. In the European medieval 
canon law era, the Christian doctrine of a prohibition of divorce, the church can not live together for both men and women marriage based on certain reason declared invalid marriage, the creation of invalid marriage theory. In modern society, the western countries to take the church law on marriage invalid theory and revocation, on the one hand, limit abuse for marriage invalid and revocation of the claim, on the other hand, flawed marriage of men and women with the invalid or revoked, without legal protection.

The development of invalid marriage system is lagging behind in contemporary China, the marriage law of 1950 and 1980 did not make provision for the invalidity of marriage, according to different conditions, which shall be subject to administrative sanction and legal sanctions. The Ministry of Civil Affairs issued the February 1, 1994 "marriage registration regulations" and established the prototype system of our country marriage invalid, although simply provides for the invalid, revocable marriage views, but has played a positive role to prevent and stop the illegal marriage. However, there are no clear rules on how to confirm the invalid marriage, the confirmation procedure and the legal consequences of the invalid marriage. At this time, China's marriage system is still in a state of incomplete. "Marriage law" established the basic content of invalid marriage system in our country with three terms, according to the difference of the party's breach of marriage, the invalid marriage is divided into invalid marriage and revocable marriage.

\section{Analysis on the defects of invalid marriage system}

Defects of statutory subject matter. The marriage law stipulates: invalid marriage with one of the following circumstances: (a) bigamy; (b) a prohibition of marriage between relatives; (c) under the legal age. Article eleventh stipulates: in case of coercion, the coerced party may request the marriage registration office or the people's court to cancel the marriage. Thus, the basic structure of the invalid marriage system of China's marriage law, it has taken void before the fact and revocable dual track system. The two element structure legislation is in line with the development trend of the world marriage law, and is more conducive to the protection of the interests of the parties concerned and their children.

The important conditions of the establishment of marriage is divided into public and private elements elements by foreign marriage scholars. Contrary to the public requirements, thought to be harmful to the society, and thus for invalid marriage; against private elements, which is considered less harmful to society, which is regard as the revocable marriage. From the foreign legislative trend invalid marriage system, difference between invalid marriage and revocable marriage is gradually reduced, but the general trend is gradually reducing the invalid marriage types, corresponding to expand the scope of revocable marriage

\section{Defects in legal consequences}

The retroactivity of invalid marriage. The provisions of the marriage law: "invalid or dissolved marriage is invalid from its inception. The marriage law judicial interpretation the provisions: Twelfth marriage law stipulated the invalid from its inception, refers to the invalid or dissolved marriage in accordance with the law has been declared invalid or revoked, which determine the marriage was not protected by law.Therefore, the marriage law for the invalid marriage and revocable marriage are taking retroactivity principle, since marriage was invalid. However, the marriage relationship is valid only if the reason for invalid or revocable marriage has not been declared invalid or revoked according to law.

In the author's point view that retroactivity of the invalid marriage and revocable marriage should be different. As mentioned earlier, invalid marriage due to serious violation of social welfare requirements, in violation of public order and good customs of society, it should be invalid fits 
inception. And revocable marriage is only a general violation of private elements of society, the law degree is not very serious, from the date of revocation is declared invalid, the revocation of the declaration before marriage is still effective, the people's court to revoke the declaration of retroactive effect. If in accordance with the general principle of retroactivity, apparently will be very unfair consequences, Taiwan scholars have discussed the effect of revocation with retroactive effect. But the law has special provisions, in accordance with its provisions, such as the provisions of marriage cancellation effect, not retroactive. So, a void marriage and revocable retroactivity should be provided separately.

The marriage law stipulates that the parties do not have the rights and obligations of husband and wife. The same with the first point, invalid marriage shall be invalid from its inception, got retroactive effect; revocation of marriage shall be null and void from the date of revocation, got no retroactive effect. The revocable marriage without retroactive effect, before the revocation of the declaration, the marriage is valid, so in the revocation of the declaration before the parties between the husband and wife relationship should also be recognized, with the rights and obligations between husband and wife.

Defects of the declaration organ. The marriage law stipulates: in case of coercion, the coerced party may request the marriage registration office or the people's court to cancel the marriage. We cansee that declaration organ of China's invalid marriage: first, the marriage registration authority, second, the people's court. On announcing the marriage invalid organs,by the way of litigation declared by the people's court, it is the universal law throughout the world,

The author believes that, in our country, it is only limited to the court to confirm and declare the nullity of marriage. In our country, the marriage registration office is located in the civil affairs departments at all levels of government, which is the state administrative organs, the marriage registration office registration act is a specific administrative, the marriage registration authority for registration of citizens is the function of marriage or divorce, to the validity of the marriage to be identified, no more on the effectiveness of marriage there is no such a declaration. Moreover, marriage is a civil legal relationship rather than an administrative legal relationship, the judgment of the validity of civil relations is the authority of the state judicial organs, rather than the authority of the state administrative organs. At the same time, not only limited to the annulment of the marriage relationship termination in accordance with the law, also involves the matters of property division. If the marriage registration authority announced that the marriage is invalid, it is inevitable that the administrative power is too much interference in private life, it is not conducive to the protection of civil rights and interests of the parties. Only the people's court may represent the state and exercise judicial power, make substantive judgments on the effectiveness of the marriage of the parties concerned, and make judgments on the relevant legal consequences.

\section{Legislative suggestions on invalid marriage system}

The establishment of marriage registration publicity system, to make up for the current situation of China's marriage registration organ registration review ineffective. In order to effectively prevent the establishment of invalid marriage, we must strengthen social supervision, and strengthen the supervision of the ideal measures, it is to establish marriage registration publicity system. The basic situation of men and women by the marriage registration department will apply for marriage, and marriage date will be noticed, in the notice period, all familiar with the marriage of the parties who can supervise the obstacles to the marriage, objection and report on marriage, disorder denounced by the court conduct trial. In the notice period, if no one reported or raised objections, or objections were rejected due to false reports, the parties have to be held on the date of the announcement of the 
wedding ceremony. Such as France, Switzerland, Italy and other countries take in the civil code provisions of the marriage announcement system.

To confirm and declare the nullity of marriage shall be limited to the court, that is to say, the proceedings shall adopt a single procedure.

c. Invalid marriage shall be invalid from its inception, got retroactive effect; revocation of marriage shall be null and void from the date of revocation, got no retroactive effect.

After the declaration of marriage is invalid, the bona fide parties should make the marriage similar to the legal consequences of divorce.

The children as legitimate children, the court to make the marriage invalid judgment, shall make a ruling to child custody.

The establishment of the system of invalid marriage. If a party's malicious acts is invalid or canceled due to the act of one party to the other party, the Party of the malicious party shall bear the civil liability for damages.

\section{Conclusion}

In a word, it is the most important to establish the basic value orientation of legislation in our country. The invalid marriage system in the developed countries of the world, all clearly embodies the modern civil law protect the bona fide party and the interests of children, with particular attention to the purpose of legislation to protect the interests of the vulnerable, so the invalid marriage system in China should be paid equal attention to the vulnerable groups of civil sanctions violations and protect the rights and interests of marriage. Only in this way can we keep up with the current trend of the invalid marriage legislation, in order to promote the healthy development of our marriage and family in twenty-first century.

\section{References:}

[1] Xia Q. Education Strategy Research on the Inheritance of the Traditional Sports Culture of Minority Ethnic[J]. Journal of Sports \& Science, 2010.

[2] Huang S, Xiao-Yan G U, Zhang D X, et al. On the Cultural Value and Inheritance Strategy of the Traditional Sports of Shui Ethnic Group[J]. Journal of Qiannan Normal College for Nationalities, 2006, 56(4):548-57.

[3] Jin D G. Discussed Shui Ethnic Group's Intangible Cultural Heritage of the Development, Utilization and Protection[J]. Journal of Bijie University, 2012.

[4] He Y, Wen B, Shan KR. [The distribution of Y-chromosome haplotypes of Shui ethnic in Sandu,Guizhou].[J]. Hereditas, 2003, 25(3):249-252.

[5]Yang Z F. Analysis on Invalid Marriage in the People's Republic of China[J]. Journal of Huanggang Polytechnic, 2010.

[6]Zhou H. Superficial Analysis On Invalid Marriage And Marriage Which Can Be Cancelled Institution Of Our Country[J]. Journal of Hubei Tv University, 2004, 30(6):27-29.

[7]Livingstone F B. A Formal Analysis of Prescriptive Marriage Systems Among The Australian Aborigines[J]. Journal of Anthropological Research, 1959, 15(Volume 15, Number 4):361-372.

[8] Quadrio C. Analysis and system: a marriage.[J]. Australian \& New Zealand Journal of Psychiatry, 1986, 20(2):219.

[9] Ding G Q. Economic Analysis on Chinese Marriage Effective System[J]. Journal of Shaoguan 
University, 2006.

[10] Chen F, Chen C. Innovative Application of Grey System Power Model and the Forecasting of Chinese Real Effective Exchange Rate under Information Fluctuation with Saturated Mode[C]// International Conference on Information Management, Innovation Management and Industrial Engineering. IEEE, 2011:432-435.

[11] Ersdal A M, Cecilio I M, Fabozzi D, et al. Applying model predictive control to power system frequency control[C]// Innovative Smart Grid Technologies Europe. IEEE, 2013:1-5.

[12] Shiroei M, Ranjbar A M, Amraee T. A functional model predictive control approach for power system load frequency control considering generation rate constraint[J]. International Transactions on Electrical Energy Systems, 2011, 23(2):214-229.

[13] Fox M A. Method, system and apparatus for life issue tracking: US, US20050251425[P]. 2005.

[14] Zhang L J, Zhang J. Method and apparatus for modeling and managing quality of service (QoS) in a service-oriented architecture (SOA) environment[J]. 2012.

[15] Shanmugasundaram G, Prasanna Venkatesan V, Punitha Devi C. Strength Estimation of Relation between Metrics in Evolution based Model[J]. International Journal of Computer Applications, 2012, 41(4):11-19.

[16] Shrivastava S, Sharma A. An approach for QoS based fault reconfiguration in service oriented architecture[C]// International Conference on Information Systems and Computer Networks. IEEE, 2013:180-184.

[17] Mahdian F, Rafe V, Rafeh R, et al. Considering Faults in Service-Oriented Architecture: A Graph Transformation-Based Approach[C]// International Conference on Computer Technology and Development. IEEE Computer Society, 2009:179-183. 